\title{
PhoE PROTEIN PORE OF THE OUTER MEMBRANE OF ESCHERICHIA COLI K12 IS A PARTICULARLY EFFICIENT CHANNEL FOR ORGANIC AND INORGANIC PHOSPHATE
}

\author{
JAAP KORTELAND *, JAN TOMMASSEN and BEN LUGTENBERG \\ Department of Molecular Cell Biology and Institute for Molecular Biology, State University, Transitorium 3, Padualaan 8, 3584 CH \\ Utrecht (The Netherlands)
}

(Received April 28th, 1982)

Key words: Outer membrane; Pore protein; PhoE protein; Phosphate channel; (E. coli)

This study was undertaken to investigate the proposed in vivo pore function of PhoE protein, an Escherichia coli K12 outer membrane protein induced by growth under phosphate limitation, and to compare it with those of the constitutive pore proteins $\mathrm{OmpF}$ and $\mathrm{OmpC}$. Appropriate mutant strains were constructed containing only one of the proteins $\mathrm{PhoE}, \mathrm{OmpF}$ or $\mathrm{OmpC}$, or none of these proteins at all. By measuring rates of nutrient uptake at low solute concentrations, the proposed pore function of PhoE protein was confirmed as the presence of the protein facilitates the diffusion of $P_{i}$ through the outer membrane, such that a pore protein deficient strain behaves as a $K_{m}$ mutant. Comparison of the rates of permeation of $P_{i}$, glycerol 3-phosphate and glucose 6-phosphate through pores formed by PhoE, OmpF and OmpC proteins shows that PhoE protein is the most effective pore in facilitating the diffusion of $P_{i}$ and phosphorus-containing compounds. The three types of pores were about equally effective in facilitating the permeation of glucose and arsenate. Possible reasons for the preference for $P_{i}$ and $P_{i}$-containing solutes are discussed.

\section{Introduction}

The outer membrane of Escherichia coli $\mathrm{K} 12$ contains two kinds of non-specific channels, formed by the two antigenically related [1] proteins OmpC and OmpF protein, respectively, which facilitate the permeation of hydrophilic solutes with a molecular weight of up to approx. 700 daltons by a diffusion-like process [2-7]. Growth of $E$. coli under conditions of phosphate limitation results in derepression of the synthesis of a new outer membrane protein [8] which is antigenically related to the other two pore proteins [1]. This protein has previously been designated as protein Ic [9], e [10] or E [11] but should be named PhoE

* Correspondence should be sent to: Jaap Korteland at the Department of Molecular Cell Biology. protein [12] as according to the new uniform nomenclature system these proteins are designated after their structural gene [13]. In addition to PhoE protein, the cell synthesizes a large number of other proteins $[14,15]$ as a reaction on phosphate limitation, e.g. periplasmic alkaline phosphatase [16], periplasmic binding proteins for $\mathrm{P}_{\mathrm{i}}[17]$ and glycerol 3-phosphate [18] (the products of the genes phoA, phoS and $u g p B$, respectively) and cytoplasmic membrane carriers involved in the transport of $P_{i}[19]$ and glycerol 3-phosphate [18] (the products of the genes pst and ugpA, respectively). It should be noted that under conditions of sufficient $P_{i}$, transport of this ion is largely dependent on the product of the pit gene.

In vivo experiments suggest that $\mathrm{PhoE}$ pores, like $\mathrm{OmpF}$ and $\mathrm{OmpC}$ protein pores, are general diffusion channels [5-7,11,20]. Growth experiments carried out before the conditions of PhoE 
protein induction were known even indicate that $P_{i}$ can diffuse through all these channels [21]. These results give rise to questions like whether PhoE protein really forms a pore and if so, why the cell, under conditions of phosphate limitation, partly replaces OmpC protein pores and OmpF protein pores by the apparently very similar PhoE protein pores. In the present paper we describe experiments in which the efficiencies are determined with which the three types of pores facilitate permeation of various solutes through the outer membrane. The results show that the PhoE protein indeed forms a pore in vivo and that it even is the most effective pore in facilitating the diffusion of $\mathrm{P}_{\mathrm{i}}$ and of $\mathrm{P}_{\mathrm{i}}$-containing solutes.

\section{Materials and Methods}

\section{Bacterial strains and phages}

All bacterial strains used in this study are derivatives of $E$. coli $\mathrm{K} 12$. The sources and relevant characteristics of the strains are listed in Table I. Conjugation and P1 transduction were carried out as described before $[24,25]$. E.coli phages T3, T4, T7, C21, P1 (all specific for lipopolysaccharide), Me1, TuIa and TC45, specifically recognizing OmpC protein, OmpF protein and PhoE protein, respectively, were from laboratory stocks.

\section{Isolation and characterization of cell fractions}

Unless indicated otherwise cells were grown in yeast broth [26] at $37^{\circ} \mathrm{C}$ under aeration. If uptake of glucose 6-phosphate, glycerol 3-phosphate or glucose was to be measured, the growth medium was supplemented with $2 \mathrm{~g} / 1$ of these solutes in order to induce the uptake systems [27,28]. After growth overnight the suspension was 10 -fold diluted in $50 \mathrm{ml}$ of prewarmed medium and incubated at $37^{\circ} \mathrm{C}$ under aeration. After the exponentially growing cells had reached a cell concentration of approx. $4 \cdot 10^{8} \mathrm{cells} / \mathrm{ml}, 30 \mathrm{ml}$ of the suspension was used for the isolation of cell envelopes in order to check the membrane protein pattern whereas the remaining $20 \mathrm{ml}$ was used for uptake experiments.

Cell envelopes were isolated as described in Ref. 29. SDS (sodium dodecyl sulphate) polyacrylamide gel electrophoresis [29] was used to analyze protein patterns. The amounts of pore protein were determined by gel scanning [29].

\section{Uptake experiments}

Uptake medium consisted of a Hepes ( $N$-2-hydroxyethylpiperazine- $N^{\prime}$-2-ethanesulfonic acid)buffered minimal salts medium without added phosphate and supplemented with the auxotrophic requirements in the appropriate concentrations. The basic medium contained (per liter): Hepes, $29.75 \mathrm{~g} ; \mathrm{NaCl}, 4.65 \mathrm{~g} ; \mathrm{KCl}, 1.5 \mathrm{~g} ; \mathrm{NH}_{4} \mathrm{Cl}, 1.08 \mathrm{~g}$; $\mathrm{Na}_{2} \mathrm{SO}_{4}, 0.425 \mathrm{~g} ; \mathrm{MgCl}_{2} \cdot 6 \mathrm{H}_{2} \mathrm{O}, 0.2 \mathrm{~g} ; \mathrm{CaCl}_{2}$. $2 \mathrm{H}_{2} \mathrm{O}, 29.5 \mathrm{mg} ; \mathrm{FeCl}_{3}, 0.54 \mathrm{mg}$ [30]. The final pH was 7.2. Membrane filters (Schleicher and Schüll, type BA 85 , pore diameter $0.45 \mu \mathrm{m}$ ) used in the uptake experiments had been soaked for $24 \mathrm{~h}$ in a solution containing solute in a concentration at least 10 -fold higher than used in the uptake experiments. Just prior to the uptake experiment filters were rinsed in demineralized water and washed with uptake medium.

The following radioactive solutes were used for uptake experiments. ${ }^{32} \mathrm{P}_{\mathrm{i}}, \quad \mathrm{L}-\left[\mathrm{U}-{ }^{14} \mathrm{C}\right] \mathrm{glycerol} 3-$ phosphate, D- $\left[\mathrm{U}-{ }^{14} \mathrm{C}\right]$ glucose 6-phosphate, D-[U$\left.{ }^{14} \mathrm{C}\right]$ glucose and $\left[{ }^{74} \mathrm{As}\right]$ arsenate. The specific activities of the radiolabelled solutes used in uptake experiments were in the range of 0.1 to $2.0 \mathrm{Ci} / \mathrm{m}$ mol. All radioactive chemicals were purchased from The Radiochemical Centre, Amersham, Bucks, U.K. Radioactive solutions of predetermined specific activity were prepared one day before use, filtered through a membrane filter and stored overnight at $4^{\circ} \mathrm{C}$. Cell concentrations used in the uptake experiments were dependent on the nature and concentration of the solute and on the uptake activity of the strain in question. They were chosen such that in no case more than $10 \%$ of the solute was taken up during the first $60 \mathrm{~s}$ of incubation. To check whether the cell-bound radio activity was not an artefact but the result of active transport, uptake experiments were also carried out in the presence of $0.5 \mathrm{mM} N$-ethylmaleimide, a sulfhydryl reagent.

Twenty $\mathrm{ml}$ of a suspension of exponentially growing cells were centrifuged at room temperature, washed twice with uptake medium, resuspended in $10 \mathrm{ml}$ uptake medium and adjusted to the appropriate cell density. Subsequent storage of the cells at room temperature for a maximal period 
of two hours did not influence their uptake behaviour. Approximately $1 \mathrm{~h}$ before the uptake experiment glucose was added in a final concentration of $0.2 \%$ and the cells were further incubated at room temperature. The cell density of the suspensions did not significantly change during this period. Subsequently the cells were prewarmed at $37^{\circ} \mathrm{C}$ for $8 \mathrm{~min}$. Uptake was started by the addition of $200 \mu \mathrm{l}$ of a solution of radiolabelled solute to $1.8 \mathrm{ml}$ of the magnetically stirred cell suspension. After various time intervals (varying from $6 \mathrm{~s}$ to $1 \mathrm{~min}$ ), registered by a foot-operated recorder, samples of $50 \mu 1$ were filtered and the cells were immediately washed three times with $2.0 \mathrm{ml}$ of uptake medium. The total washing procedure lasted no longer than $5 \mathrm{~s}$. After drying at the air, $10 \mathrm{ml}$ of toluene-based scintillation fluid, containing $50 \mathrm{mg}$ PPO (2,5-diphenyloxazole) and $0.5 \mathrm{mg}$ POPOP (1,4-di-2(5-phenyloxazolyl) benzene) was added and the radioactivity on the filter was determined. Incubations without cells were carried out as a control. Uptake was expressed in $\mathrm{nmol}$ per min per mg dry weight cells.

\section{Results and Discussion}

\section{Construction of strains}

We wanted to compare the presumed pore activity of PhoE protein with those of OmpC protein and $O m p F$ protein in vivo. We thus had to construct three isogenic strains constitutively producing only one pore protein as well as a strain lacking all three of these pores. The latter strain was required as a control in order to check whether the measured permeation was indeed due to the pores under study. As we wanted to study the pore activity in the presence of the phosphate binding protein, we could not use a phos mutation for the construction of a strain with high levels of $\mathrm{PhoE}$ protein but we were dependent on a phoR mutation. However, phoR strains produce relatively little PhoE protein [30], but this problem was solved by the discovery that strain $\mathrm{C} 3$, carrying the phoR69 mutation and known to produce high levels of alkaline phosphatase [31], is exceptional in that it produces high levels of $\mathrm{PhoE}$ protein. Therefore this phoR69 allele was crossed into ompB strain CE1107 which resulted in strain CE1230, which produces PhoE protein as the only pore protein.

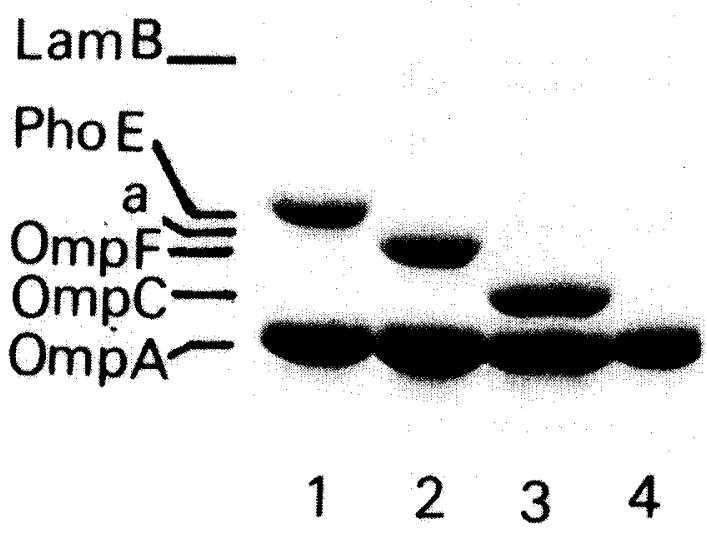

Fig. 1. Cell envelope protein patterns of isogenic strains producing only one pore protein. The slots contain cell envelope preparations of the following strains: (1) CE1230, (2) CE1233, (3) CE1234, (4) CE1231. Only the relevant part of the gel is shown. Protein $a$ is a minor outer membrane protein with approximately the same electrophoretic mobility as $\mathrm{PhoE}$ protein [10]. LamB protein functions as a pore with substrate specificity for maltose and maltodextrins [32]. Molecular weights of the relevant proteins are between 47000 (for LamB protein) [33] and 35000 (for OmpA protein) [34].

From this strain isogenic derivatives producing no pore protein at all or only $\mathrm{OmpC}$ protein or $\mathrm{OmpF}$ protein were constructed (Table I). Similarly, in order to prevent degradation of alkaline phosphatase sensitive solutes, a series of strains containing the phoA mutation was constructed by first constructing strain CE1236, a phoA derivative of strain $\mathrm{C} 3$, and subsequently using this strain as a donor of the phoR69 allele instead of strain C3.

The cell envelope protein patterns of the three strains containing only one pore, and of the pore protein deficient strain, are shown in Fig. 1. The results of scanning of the gels (Table II) show that the amount of pore protein expressed either relative to OmpA protein or to total cell envelope protein is practically constant whereas the amount of OmpA protein over the amount of total cell envelope protein is 2 -fold higher in the pore protein deficient strain than in the other three strains, consistent with data reported earlier [35-39]. As the results indicate that the amount of pore protein per unit of cell surface is not significantly different for the three pore protein containing 
TABLE I

BACTERIAL STRAINS AND RELEVANT PROPERTIES ${ }^{a}$

\begin{tabular}{|c|c|c|c|c|c|c|}
\hline \multirow[t]{2}{*}{ Strain } & \multirow[t]{2}{*}{ Relevant characteristics } & \multicolumn{4}{|c|}{ Relevant protein pattern ${ }^{b}$} & \multirow[t]{2}{*}{ Source $^{c}$, reference } \\
\hline & & OmpF & OmpC & PhoE & PhoA & \\
\hline PC0479 & $\begin{array}{l}\mathrm{F}^{-}, \text {thr, leu, thi, pyrF, thy, ilv } A, \\
\text { his, lac } Y, \arg G, \operatorname{ton} A, \operatorname{ts} x, \operatorname{rps} L \\
\text { cod, dra, vtr, glpR }\end{array}$ & + & + & - & + & $\mathrm{PC}$ \\
\hline CE1107 & ompB47I derivative of $\mathrm{PC} 0479$ & - & - & - & + & Ref. 22 \\
\hline C3 & $\begin{array}{l}\mathrm{HfrC}, \text { phoR69, ompF, relA1, pit-10, } \\
\text { spoTl, tonA22, } \mathrm{T}_{2}^{\mathrm{R}}\end{array}$ & - & + & + & + & $\begin{array}{l}\text { A. Torriani via } \\
\text { CGSC }\end{array}$ \\
\hline CE1230 & $\begin{array}{l}\text { thr }{ }^{+} \text {, leu }{ }^{+} \text {, phoR69, ompB47l, ilA } \\
\text { derivative of CE1 } 107 \text { obtained by } \\
\text { conjugation with strain } \mathrm{C} 3 \text { as the } \\
\text { donor }\end{array}$ & - & - & + & + & This study \\
\hline CE1231 & $\begin{array}{l}\text { TC45 resistant phoE pro derivative } \\
\text { of CE } 1230\end{array}$ & - & - & - & + & $\begin{array}{l}\text { This study and } \\
\text { reference } 12\end{array}$ \\
\hline CE1232 & SDS resistant derivative of CE1231 & + & + & - & + & This study \\
\hline CE1233 & Mel resistant derivative of $\mathrm{CE} 1232$ & + & - & - & + & This study \\
\hline CE1234 & Tula resistant derivative of CE1232 & - & + & - & + & This study \\
\hline CE1235 & EMS induced pro $C$ derivative of $\mathrm{C} 3$ & - & + & + & + & This study \\
\hline $\operatorname{Lin} 8$ & $\begin{array}{l}g l p R 2, g l p D 3, \text { phoA } 8, \text { relA1, tonA22, } \\
\mathrm{T}_{2}^{\mathrm{R}}\end{array}$ & + & + & - & - & CGSC \\
\hline CE1236 & $\begin{array}{l}\text { pro } C^{+} \text {, phoA } 8 \text { transductant of CE1235 } \\
\text { obtained using a P1 lysate grown on } \\
\text { strain Lin8 }\end{array}$ & - & + & + & - & This study \\
\hline CE1237 & $\begin{array}{l}t h r^{+}, \text {leu } \\
\text { derivative of } \text { CE1 } 107 \text { obtained by con- } \\
\text { jugation using strain CE1236 as the donor }\end{array}$ & - & - & + & - & This study \\
\hline CE1238 & $\begin{array}{l}\text { TC45 resistant phoE, pro derivative } \\
\text { of CE } 1237\end{array}$ & - & - & - & - & This study \\
\hline CE1239 & SDS resistant derivative of CE1238 & + & + & - & - & This study \\
\hline CE1240 & Mel resistant derivative of CE1239 & + & - & - & - & This study \\
\hline CE1241 & Tula resistant derivative of CE1239 & - & + & - & - & This study \\
\hline
\end{tabular}

a Genotype descriptions follow the recommendations of Bachmann and Low [23] except for phoE which represents the structural gene for PhoE protein [12].

b + and - , present and absent, respectively, during the uptake experiment after growth under the described conditions.

c PC, Phabagen Collection, Department of Molecular Cell Biology, section Microbiology, State University of Utrecht, Utrecht, The Netherlands: CGSC, E. coli Genetic Stock Center, Department of Human Genetics, Yale University School of Medicine, New Haven, CT, U.S.A. (Bachmann, B.J., curator).

strains, the uptake data were not corrected for the slight differences in the relative amounts of pore protein.

In vivo rates of $P_{i}$ permeation through $P$ hoE protein pores

Rates of permeation of solutes through diffu- sion pores are dependent on the differences in solute concentrations at both sides of the pore. This explains why the rate of permeation through the outer membrane is the limiting step in an uptake assay only at very low solute concentrations, usually in the $\mu M$ range $[3,4,6,10,40]$. Fig. 2 shows the results of $P_{i}$ uptake for the pore protein 
TABLE II

\section{RELATIVE AMOUNTS OF PORE PROTEIN IN STRAINS CONTAINING ONE PORE PROTEIN}

Cell envelopes were isolated by differential centrifugation and the protein patterns obtained after SDS-polyacrylamide gel electrophoresis were scanned as described in Materials and Methods.

\begin{tabular}{llcl}
\hline Strain & Pore protein present & $\begin{array}{l}\text { Ratio pore protein over } \\
\text { OmpA protein } \\
(\mu \mathrm{g} / \mu \mathrm{g})\end{array}$ & $\begin{array}{l}\text { Ratio OmpA protein } \\
\text { over total cell envelope protein } \\
(\mu \mathrm{g} / \mu \mathrm{g})\end{array}$ \\
\hline CE1230 & PhoE protein & 0.52 & 0.25 \\
CE1233 & OmpF protein & 0.55 & 0.28 \\
CE1234 & OmpC protein & 0.50 & 0.24 \\
CE1231 & None & $<0.01$ & 0.56 \\
\hline
\end{tabular}

deficient strain CE1231 and the isogenic PhoE protein containing strain $\mathrm{CE} 1230$. As the presence of outer membrane PhoE protein causes a large increase in the rate of uptake it is clear that the outer membrane limits the rate of uptake in strain CE1231. The inhibitory effect of the sulfhydryl reagent $N$-ethylmaleimide shows that $\mathrm{P}_{\mathrm{i}}$ uptake is a process of active transport.

Lineweaver-Burk plots were constructed to obtain $K_{\mathrm{m}}$ and $V_{\max }$ values for $\mathrm{P}_{\mathrm{i}}$ uptake by strains CE1230 and CE1231 (Fig. 3). The $K_{\mathrm{m}}$ values obtained were $1.9 \pm 0.2$ and $18.2 \pm 1.4 \mu \mathrm{M}$, respectively, whereas $V_{\max }$ values of $35.7 \pm 2.5$ and 30.4 $\pm 2.7 \mathrm{nmol}_{\mathrm{i}}$ per $\mathrm{mg}$ dry weight per min, respec-

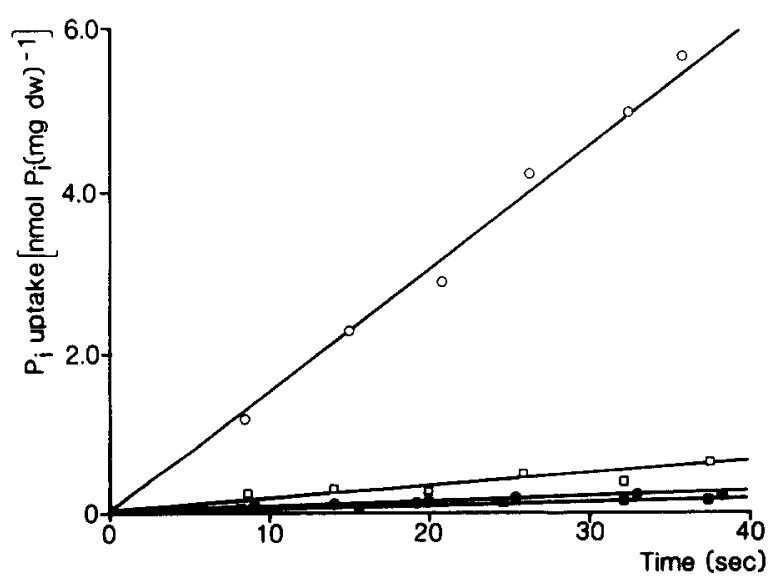

Fig. 2. $P_{i}$ accumulation by cells of strain CE1230 and strain CE1231. Open symbols represent uptake of $P_{i}$ at a concentration of $0.7 \mu \mathrm{M}$, whereas closed symbols represent the same experiments except that the cells had been preincubated for 4 min with $N$-ethylmaleimide $(0.5 \mathrm{mM})$. $(\mathrm{O}, 0)$, strain CE1230 containing PhoE protein; $(\square, \square)$, strain CE1231 lacking all pore proteins. tively, were calculated. Thus the $V_{\max }$ value of the PhoE protein deficient strain is not significantly altered but its $K_{\mathrm{m}}$ value is strongly increased. Consequently the presence of PhoE protein decreases the $K_{\mathrm{m}}$ value for $\mathrm{P}_{\mathrm{i}}$ transport across the outer membrane. Thus the kinetic data indicate that PhoE protein facilitates permeation of solutes through the membrane in a similar way as is known for the $\mathrm{OmpF}$ and $\mathrm{OmpC}$ pore proteins $[2-7,40]$. During the course of this work a similar conclusion was drawn from in vitro experiments [41].

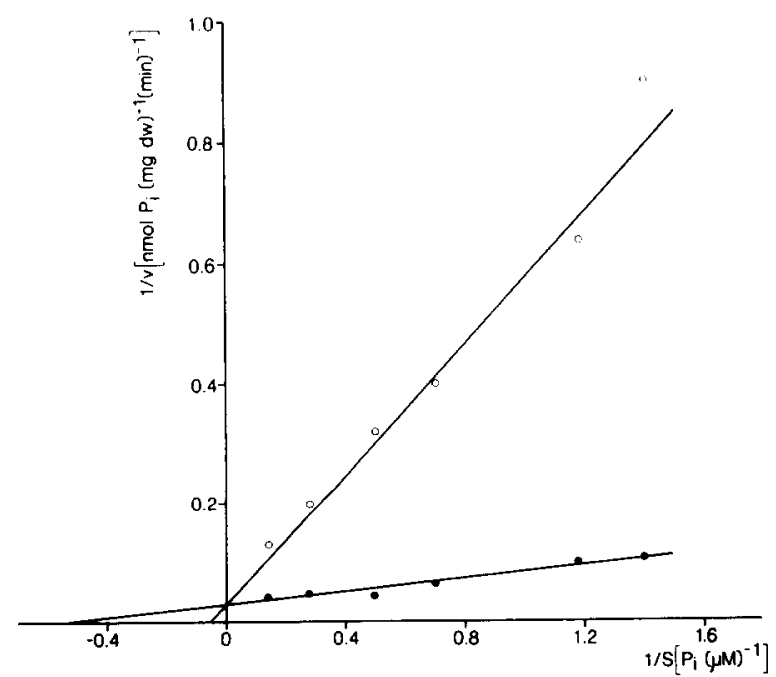

Fig. 3. Lineweaver-Burk plots for $P_{i}$ accumulation by cells of strain CE1230 and strain CE1231. The rate of permeation across the outer membrane was assayed at concentrations varying from 0.7 to $6.9 \mu \mathrm{M} \mathrm{P}_{\mathrm{i}}$. $\bullet$, strain $\mathrm{CE} 1230$ producing PhoE protein; $O$, strain CE1231 lacking all pore proteins. 
Comparison of pore properties of PhoE, OmpF and OmpC proteins

The results of a number of experiments, in which rates of permeation of a series of solutes through various pores in the outer membrane were determined, are listed in Table III. The data show that, compared with the other two pores, the PhoE protein pore is particularly efficient for the permeation of $P_{i}$, glycerol 3-phosphate and glucose 6-phosphate. When the latter solute is replaced by glucose, the rate of permeation through the $\mathrm{PhoE}$ protein pore is not significantly influenced whereas those through the other two pores strongly increase. These results show that the presence of the phosphate moiety, which increases the size of the solute and gives it a strong negative charge, is disadvantageous for the efficiencies of the OmpC protein and OmpF protein pores but not for that of the PhoE protein pore.

In contrast to inorganic phosphate, arsenate, another anion, permeates about equally well through all three pores with rates similar to those observed for the rates of inorganic phosphate through the $\mathrm{OmpF}$ and $\mathrm{OmpC}$ protein pores but considerably slower than the rate of permeation of
$P_{i}$ through the PhoE protein pore. Thus, although the PhoE pore clearly has a preference for phosphate moieties, it obviously does not excert this preference on anions in general. The results indicate that the PhoE protein pore is an equally good or even a better pore than the OmpC and OmpF protein pores for the unrelated solutes arsenate and glucose, showing that it has general pore properties. In addition, the data indicate that the PhoE protein pore is considerably more efficient than the other pores in the uptake of $P_{i}$ and $\mathrm{P}_{\mathrm{i}}$-containing solutes, a phenomenon which cannot be explained by a simple general diffusion pore mechanism.

The pore protein deficient strain has some striking permeability properties (Table III). The considerable 'background' activity observed for inorganic phosphate and glucose cannot be the result of residual activity of the pores under study, since the pore activity for the other solutes was extremely low. Therefore the former two solutes, but not the other ones, must be able to use another pore in the outer membrane for which the LamB protein pore and the $\mathrm{T} 6$ receptor protein pore are obvious candidates $[42,43]$.

TABLE III

RATE OF PERMEATION OF VARIOUS SOLUTES ACROSS THE OUTER MEMBRANE OF ISOGENIC STRAINS PRODUCING ONLY ONE GENERAL DIFFUSION PORE PROTEIN

Alkaline phosphatase constitutive strains CE1230, CE1231, CE1233 and CE1234 were used in case of inorganic phosphate and arsenate. The experiments with the other solutes were carried out with the alkaline phosphatase deficient series of strains CE1237, CE1238, CE1240 and CE1241. For details, see Table I.

\begin{tabular}{llllll}
\hline Solute $^{\mathrm{a}}$ & $\begin{array}{l}\text { Concn. } \\
(\mu \mathrm{M})\end{array}$ & \multicolumn{2}{l}{ Rate (nmol substrate per min per (mg dry weight) } \\
\cline { 3 - 6 } & & Pore used for uptake & & \\
\cline { 3 - 6 } & & PhoE protein & OmpF protein & OmpC protein & 'None' \\
\hline Inorganic phosphate & 0.7 & $9.1(100 \%)$ & $2.0(12 \%)$ & $4.6(44 \%)$ & 1.0 \\
Glycerol 3-phosphate & 1.2 & $2.5(100 \%)$ & $0.43(17 \%)$ & $0.43(17 \%)$ & $<0.01$ \\
Glucose 6-phosphate & 1.0 & $1.3(100 \%)$ & $0.30(23 \%)$ & $0.22(17 \%)$ & $<0.01$ \\
Glucose & 1.0 & $1.4(100 \%)$ & $1.1(75 \%)$ & $1.4(100 \%)$ & 0.2 \\
Arsenate & 1.0 & $3.2(100 \%)$ & $3.7(116 \%)$ & $2.6(81 \%)$ & $<0.01$ \\
\hline
\end{tabular}

Solute concentrations used are lower than $K_{\mathrm{m}}$ values.

b Initial rates are listed. The results are averages of at least three experiments. The maximal standard deviation of the values is 0.06 .

c Assuming that the uptake activity by the pore protein deficient strain is the result of permeation through other pores than the studied ones, relative rates have been calculated by subtracting the value found for the pore-deficient strain from that found for the pore-containing strains and by subsequently setting the values for the PhoE protein pore at $100 \%$. 
In the course of our work experiments with black lipid films have been reported which show that the PhoE protein indeed forms a general diffusion pore with a pore diameter of $1.2 \mathrm{~nm}$, a size similar to those determined for the OmpC (1.3 $\mathrm{nm})$ and $\mathrm{OmpF}$ protein $(1.4 \mathrm{~nm})$ pores [41]. As it has been calculated from molecular models that $\mathrm{HPO}_{4}^{2-}$ and $\mathrm{H}_{2} \mathrm{PO}_{4}^{-}$ions have diameters of 0.56 nm (Hancock, R.E.W., personal communication) all three channels therefore are large enough to allow the diffusion of these ions. Moreover the work with black lipid films has shown that the PhoE protein pore has a preference for anions (Benz, R. and Henning, U., cited in Ref. 18). The latter phenomenon, as well as the observations that PhoE protein is induced by phosphate limitation [8], that it forms a relatively good pore for the negatively charged antibiotic cefsulodin in vivo [44] and that the PhoE protein pore in vivo has a preference for inorganic and organic phosphate (but not for arsenate) (Table III) are consistent with the assumption that the PhoE protein pore has a weak affinity site for at least some negatively charged solutes, analogous to the binding site for maltose and related compounds detected on the LamB protein pore $[45,46]$. Indeed recent experiments in our laboratory have shown that competition for uptake through the PhoE protein pore, but not through the OmpF protein pore, is observed between the negatively charged $\beta$-lactam antibiotic cefsulodin and negatively charged solutes like inorganic and organic phosphate and, surprizingly, also arsenate [44].

Whereas the present experiments (Table III) indicate a preference of the $\mathrm{PhoE}$ protein pore for phosphate residues only, which is sufficient to explain induction of the protein by phosphate limitation [8], other data (Ref. 44 and Benz, R. and Henning, U., cited in Ref. 18) rather indicate a preference for anions in general. As the periplasmic phosphate binding protein was absent in the latter experiments but present in cells used in the experiments described in the present paper (Table III), the seemingly contradictory results on the preference of the PhoE protein pore can be explained by assuming that the presence of the phosphate binding protein increases the specificity of the solute binding site on the PhoE protein pore. A similar role for the maltose binding pro- tein in increasing the 'specificity' of the LamB protein pore has recently been suggested [46].

\section{Acknowledgements}

The technical assistance of Lilian Joosen and Ria van Boxtel was greatly appreciated.

\section{References}

1 Overbeeke, N., Van Scharrenburg, G. and Lugtenberg, B. (1980) Eur. J. Biochem. 110, 247-254

2 Nakae, T. (1976) Biochem. Biophys. Res. Commun. 71, 877-884

3 Beacham, I.R., Haas, D. and Yagil, E. (1977) J. Bacteriol. 129, 1034-1044

4 Lutkenhaus, J.F. (1977) J. Bacteriol. 131, 631-637

5 Van Alphen, W., Van Boxtel, R., Van Selm, N. and Lugtenberg, B. (1978) FEMS Microbiol. Lett. 3, 103-106

6 Van Alphen, W., Van Selm, N. and Lugtenberg, B. (1978) Mol. Gen. Genet. 159, 75-83

7 Nikaido, H., Rosenberg, E.Y. and Foulds, J. (1982) submitted for publication

8 Overbeeke, N. and Lugtenberg, B. (1980) FEBS Lett. 112, 229-232

9 Henning, U., Schmidmayer, W. and Hindennach, I. (1977) Mol. Gen. Genet. 154, 293-298

10 Lugtenberg, B., Van Boxtel, R., Verhoef, C. and Van Alphen, W. (1978) FEBS Lett. 96, 99-105

11 Foulds, J. and Chai, T. (1978) J. Bacteriol. 133, 1478-1483

12 Tommassen, J. and Lugtenberg, B. (1981) J. Bacteriol. 147, 118-123

13 Reeves, P. (1979) in: Bacterial Outer Membranes: Biogenesis and Functions (Inouye, M., ed.), pp. 255-291, Wiley-Interscience, New York

14 Wanner, B.L., Wieder, S. and McSharry, R. (1981) J. Bacteriol. 146, 93-101

15 Tommassen, J. and Lugtenberg, B. (1982) Ann. Microbiol. (Inst. Pasteur) 133A, 243-249

16 Torriani, A. (1960) Biochim. Biophys. Acta 38, 460-470

17 Willsky, G.R. and Malamy, M.H. (1976) J. Bacteriol. 127, 595-609

18 Argast, M. and Boos, W. (1980) J. Bacteriol. 143, 142-150

19 Rosenberg, H., Gerdes, R.G. and Chegwidden, K. (1977) J. Bacteriol. 131, 505-511

20 Pugsley, A.P. and Schnaitman, C.A. (1978) J. Bacteriol. 135, $1118-1129$

21 Van Alphen, W.J.T. (1978) Ph.D. Thesis, University of Utrecht

22 Verhoef, C., Lugtenberg, B., Van Boxtel, R., De Graaff, P. and Verkleij, A. (1979) Mol. Gen. Genet. 169, 137-146

23 Bachmann, B.J. and Low, K.B. (1980) Microbiol. Rev. 44, $1-56$

24 Havekes, L.M., Lugtenberg, B.J.J. and Hoekstra, W.P.M. (1976) Mol. Gen. Genet. 146, 43-50

25 Willetts, N.S., Clark, A.J. and Low, K.B. (1969) J. Bacteriol. 97, 244-249 
26 Lugtenberg, B., Peters, R., Bernheimer, H. and Berendsen, W. (1976) Mol. Gen. Genet. 147, 251-262

27 Lin, E.C.C., Koch, J.P., Chused, T.M. and Jorgenson, S.E. (1962) Proc. Natl. Acad. Sci. U.S.A. 48, 2145-2150

28 Kornberg, H.L. and Smith, J. (1969) Nature 224, 1261-1262

29 Lugtenberg, B., Mayers, J., Peters, R., Van der Hoek, P. and Van Alphen, L. (1975) FEBS Lett. 58, 254-258

30 Tommassen, J. and Lugtenberg, B. (1980) J. Bacteriol. 143, 151-157

31 Echols, H., Garen, A., Garen, S. and Torriani, A. (1961) J. Mol. Biol. 3, 425-438

32 Luckey, M. and Nikaido, H. (1980) Proc. Natl. Acad. Sci. U.S.A. 77, 167-171

33 Clément, J.M. and Hofnung, M. (1981) Cell 27, 507-514

34 Chen, R., Schmidmayr, W., Krämer, C., Chen-Schmeisser, U. and Henning, U. (1980) Proc. Natl. Acad. Sci. U.S.A. 77, 4592-4596

35 Schnaitman, C.A. (1974) J. Bacteriol. 118, 454-464

36 Henning, U. and Haller, I. (1975) FEBS Lett. 55, 161-164
37 Schweizer, M., Schwartz, H., Sonntag, I. and Henning, U. (1976) Biochim. Biophys. Acta 448, 474-491

38 Van Alphen, W., Lugtenberg, B. and Berendsen, W. (1976) Mol. Gen. Genet. 147, 263-269

39 Chai, T.J. and Foulds, J. (1977) J. Bacteriol. 130, 781-786

40 Nikaido, H. (1979) in Bacterial Outer Membranes: Biogenesis and Functions (Inouye, M., ed.), pp. 361-407, Wiley-Interscience, New York

41 Benz, R. and Hancock, R.E.W. (1981) Biochim. Biophys. Acta 646, 298-308

42 Von Meyenburg, K. and Nikaido, H. (1977) Biochem. Biophys. Res. Commun. 78, 1100-1107

43 Hantke, K. (1976) FEBS Lett. 70, 109-112

44 Overbeeke, N. and Lugtenberg, B. (1982) Eur. J. Biochem. in the press.

45 Ferenci, T., Schwentorat, M., Ullrich, S. and Vilmart, J. (1980) J. Bacteriol. 142, 521-526

46 Bavoil, P. and Nikaido, H. (1981) J. Biol. Chem. 256, 11385-11388 